\title{
HEAVY-METAL UPTAKE BY A HIGH CATION-EXCHANGE-CAPACITY MONTMORILLONITE: THE ROLE OF PERMANENT CHARGE SITES
}

\section{P. STATHI \\ I.T. PAPADAS \\ A. TSELEPIDOU
Y. DELIGIANNAKIS*}

Received: 20/05/10

Accepted: 09/09/10

\author{
Lab of Physical Chemistry \\ Department of Environmental and Natural \\ Resources Management, University of loannina \\ 2, Seferi STR.,GR-30100 Agrinio, Greece
}

*to whom all correspondence should be addressed:

e-mail: . ideligia@cc.uoi.gr

\begin{abstract}
A High Cation Exchange Capacity ( $\mathrm{HCM}$ ) montmorillonite clay has been prepared by acetate treatment of Zenith clay. The HCM has been evaluated for metal-uptake from aqueous solutions. The present data show that the cation exchange sites can play a significant role in the adsorption of metals in smectite clays. A theoretical analysis scheme has been developed which shows that permanent-charge sites can become dominant in metal-uptake by clays. In addition, it was shown that the permanent charge can influence the ionic-strength sensitivity of the Point of Zero Charge of the clay.
\end{abstract}

KEYWORDS: Montmorillonite; CEC; Adsorption; Heavy metals; Surface Complexation Models; Permanent charge.

\section{INTRODUCTION}

Under certain environmental conditions, heavy metals might accumulate up to toxic concentrations and cause ecological damage. Heavy metals are often introduced to the environment through modern human activities. Montmorillonites are a class of layered aluminosilicate minerals with unique combinations of swelling and ion exchange properties that make them valuable nanostructures in diverse fields. Their structures consist of an octahedral alumina layer fused between two tetrahedral silica layers. Smectite clays have a cation exhange capacity, which depends on the substitution of low-valent atoms such as $\mathrm{Mg}^{2+}$ or $\mathrm{Al}^{3+}$ in the octahedral sheet, and $\mathrm{Al}^{3+}$ or $\mathrm{Si}^{4+}$ in the tetrahedral sites. As a consequence, the layers are negatively charged (Sposito, 1989; Sposito, 2004). Soluble heavy metals can be removed from the environment, by adsorption. Clay minerals are low cost sorbents and are highly valued for their adsorptive properties. Therefore, a number of studies performed using clays for heavy metal adsorption showed effectiveness in removing heavy metals or organic molecules from aqueous solutions (Ikhsan et al., 2005; Barbier et al., 2000; Bradbury and Bayens, 1999; Bayens and Bradbury, 1997). Adsorption of ions on clay minerals is controlled by two different mechanisms: (i) $\mathrm{pH}$-independent adsorption, usually attributed to cation exchange in the intrer-layer and resulting from the electrostatic interaction between the ions and the permanent charge. (ii) a $\mathrm{pH}$ dependent adsorption, thought to result from the surface complexation reaction similar to those on oxides. Cation exchange has been fount to be an important sorption mechanism for many clay minerals (Ikhsan et al., 2005; Kraepiel et al., 1999; Avena and De Pauli, 1998) with a number of studies suggesting that exchange sites are responsible for cation uptake at low $\mathrm{pH}$. Adsorption models for clays based on surface complexation modeling (SCM) usually involving two distinct types of surface groups (1) $\mathrm{X}^{-}$groups bearing a permanent charge with account to the cation exchange part of adsorption (2) amphoteric sites of SOH groups. Recently we have shown that the cation exchange capacity (CEC) of a Zn-containing montmorillonite (code name Zenith) can be increased by selective removal of $\mathrm{Zn}$ atoms from the clay lattice (Stathi et al., 2009). According to this methodology treatment with acetate allows the production of clay materials with C.E.C up to $180 \mathrm{meq} / 100 \mathrm{~g}$. This exceed by $200 \%$ the typicall C.E.C 
for smectites (Sposito, 1989; Sposito, 2004; Ikhsan et al., 2005; Barbier et al., 2000; Bradbury and Bayens, 1999; Stathi et al., 2009). In the present work, we present a physicochemical theoretical and experimental study of the metal-binding properties of the High-CEC-Montmorillonite (herein termed $\mathrm{HCM}$ ). The aim of the present work is (a) to evaluate the metal-uptake capacity of the HCM, (b) to study the role of permanent-charge-sites in the $\mathrm{H}$-binding and metal-binding properties of the $\mathrm{HCM}$, and (c) to develop a theoretical model describing the role of the permanent-charge sites.

\section{MATERIALS AND METHODS}

All solutions were prepared with analytical grade chemicals and purified water (milli-Q academic system) with a conductivity of demineralized water of $18.2 \mu \mathrm{S}$ and degassed prior to use. Solutions of $\mathrm{Pb}\left(\mathrm{NO}_{3}\right)_{2}, \mathrm{Cd}\left(\mathrm{NO}_{3}\right)_{2} \mathrm{Cu}\left(\mathrm{NO}_{3}\right)_{2}$ and $\mathrm{Zn}\left(\mathrm{NO}_{3}\right)_{2}$ (Aldrich $>99.5 \%$ ) were prepared at a concentration of $3 \mathrm{mM}$ and kept in a polyethylene container at $\mathrm{pH}<2$. A buffer system of $10 \mathrm{mM} \mathrm{N}$-morpholinoethanesulfonic acid,4-(2-hydroxyethyl)piperazine-1-ethanesulfonic acid, and tris-hydroxymethylaminomethane was used for all of the samples, which presented a significant buffer capacity at a pH range of 5-9, with an average value deviation from the adjusted initial value of up to $5 \%$. The $\mathrm{pH}$ values were adjusted with small volumes of $\mathrm{NaOH}$ or $\mathrm{HNO}$ (concentrations of 0.1 and $0.05 \mathrm{~N}$ ). Screening experiments indicated that, under the conditions of our experiments, the buffer molecules caused no interferences on the adsorption.

The montmorillonite used in this work was from the Island of Milos with a code name Zenith-N and the following chemical composition $\mathrm{Na}_{0.63} \mathrm{~K}_{0.07} \mathrm{Ca}_{0.11}\left[\mathrm{Si}_{7.75} \mathrm{Al}_{0.25}\right]-\left\{\mathrm{Al}_{3.21} \mathrm{Mg}_{0.69} \mathrm{Fe}^{+3}{ }_{0.05} \mathrm{Ti}_{0.05}\right\} \mathrm{O}_{20}(\mathrm{OH})_{4}$. The sample fractionated to $<2 \mu \mathrm{m}$ by gravity sedimentation and purified by standard methods (King et al., 1987). Sodium exchange samples were prepared by immersing the clay into $1 \mathrm{M}$ solution of sodium chloride. Cation exchange was complete by washing and centrifuging four times with sodium chloride. Then, the samples were transfered into dialysis tubes in order to obtain chloride free clays and dried at room temperature. As detailed in Stathi et al., 2009 with no-acetate treatment the CEC was $80 \mathrm{meq} / 100 \mathrm{~g}$. After acetate treatment (Stathi et al., 2009) a High CEC Montmorillonite was prepared with CEC $186 \mathrm{meq} / 100 \mathrm{~g}$. This $(\mathrm{HCM})$ material was used throughout the present work. After completion of the purification and saturation of zenith clay, $10 \mathrm{mg}$ of the sample suspended in $10 \mathrm{~mL}$ $\mathrm{HNO}_{3} 65 \%$ incubated for $48 \mathrm{~h}$ centrifuged and the supernatant analyzed by atomic absorption spectroscopy (Perkin Elmer AAS700). Full data have been presented by Stathi et al., 2009.

\subsection{Surface Charge Properties of Montmorillonite}

The surface charge of montmorillonite suspensions were evaluated by two methods: potentiometric acid -base titrations (Schulthess and Sparks, 1986; Stathi et al., 2006; Giannakopoulos et al., 2006) and mass titration (Giannakopoulos et al., 2006; Bourikas et al., 2003).

Potentiometric titrations: Acid-base potentiometric titration was used to measure the surface proton adsorption. The ionic strength of the suspension was adjusted, before the titration experiment, at $0.01 \mathrm{M}$ with $\mathrm{KNO}_{3}$ A $12.5 \mathrm{mg}$ of montmorillonite was suspended in a titration cell containing $12.5 \mathrm{~mL}$ of Milli-Q water to yield a montmorillonite concentration $1 \mathrm{~g} \mathrm{~L}^{-1}$. The suspension allowed to equilibrate (Swell) for 12 hours with continuous stirring. Then, the suspension was purged with $\mathrm{N}_{2}$ for $30 \mathrm{~min}$ prior to titration and divided into two equal portion, that is, one for acidimetric and one for alkalimetric titration. The acidimetric titration was done with $12.5 \mathrm{mM} \mathrm{HNO}_{3}$ in the $\mathrm{pH}$ range 3.00 9.25 and the alkalimetric was done with $12.5 \mathrm{mM} \mathrm{NaOH}$ with $\mathrm{pH}$ range 9.25-10.50. In all titrations the Metrohm 794 Basic Titrino buret was used, and the $\mathrm{pH}$ was measured with Metrohm Pt-glass electrode (type 6.0239.100).

Mass Titration. The mass titration method was used to determine the point of zero charge (PZC) of the clay in two ionic strengths. A $5 \mathrm{mg}$ portion of montmorillonite was added to $5 \mathrm{~mL}$ of Milli-Q water having a $\mathrm{pH}$ between 7.50 and 11.50 . The initial $\mathrm{pH}$ of the solution was adjusted with $\mathrm{HNO} 3$ or $\mathrm{NaOH}$. After each addition of $5 \mathrm{mg}$ of solid Laponite, the $\mathrm{pH}$ was measured with a Metrohm Pt-glass microelectrode (type 6.0222.100). The suspension was continuously stirred and purged by nitrogen gas. When equilibration was achieved (equilibration time $15 \mathrm{~min}$ ), a new amount of montmorillonite was added. This procedure was continued until further montmorillonite additions did not change the $\mathrm{pH}$ of the solution. This $\mathrm{pH}$ value has been shown to be a good approximation to the PZNPC of oxide and clay surfaces (Kraepiel and Morel, 1999; Avena and De Pauli, 1998; Giannakopoulos et al., 2006; Stathi et al., 2009). 


\subsection{Sorption Experiments}

The concentrations of metals in the aqueous phase were determined as described earlier (Giannakopoulos et al., 2006) for clay suspensions at concentrations $1 \mathrm{~g} \mathrm{~L}^{-1}$ with an initial concentration of $4.5 \mu \mathrm{M}$ of metal ions.

Sorption $\mathrm{pH}$-edge experiments were performed to measure the effect of $\mathrm{pH}$ on the metal uptake, as follows: zenith clay was suspended in polypropylene tubes containing a buffer system of $10 \mathrm{mM}$ MES (N-morpholino-ethanesulfonic acid), 10mM HEPES (4-(2-Hydroxyethyl)piperazine-1ethanesulfonic) was used at all of the samples. This system presented a significant buffer capacity at range $\mathrm{pH}: 5.0$ to 8.5 with an average deviation from the adjusted $\mathrm{pH}$ value $<5 \%$. Screening experiments indicated that under the conditions of our experiments the buffer molecules caused no interferences on the adsorption phenomena. The $\mathrm{pH}$ was adjusted with small volumes of $\mathrm{NaOH}(0.1 \mathrm{~N})$ or $\mathrm{HNO}_{3}(0.05 \mathrm{~N})$ and each suspension was allowed to equilibrate (swelling) for 12 hours under continuous stirring. Then, a suitable volume of metal stock solution was added to yield a metal concentration of $4.5 \mu \mathrm{M}$. The $\mathrm{pH}$ of the suspension was re-adjusted, if necessary, by using small amounts of $\mathrm{HNO}_{3}$ or $\mathrm{NaOH}$. The sample was allowed to equilibrate at room temperature for $2 \mathrm{~h}$ under stirring. Screening experiments showed that equilibrium metal-uptake equilibrium was attained within 40minutes (data not shown). The $\mathrm{pH}$ of each suspension was continuously monitored and readjusted if necessary. Typically, in the present experiment $\mathrm{pH}$ variations did not exceed $\pm 0.1 \mathrm{pH}$ units. Finally, the sample was centrifuged and the supernatant solution was analyzed for metals.

\section{THEORETICAL SURFACE COMPLEXATION MODELING}

The results of all potentiometric titration and sorption experiment were modeled with a surface complexation model. Surface complexation models (SCM) can describe successfully adsorption of ions on charged surfaces by assuming that adsorption involves both a coordination reaction at specific surface sites and an electrostatic interaction between adsorbing ions and the charged surface. Extended SCM have been used previously to describe the adsorption of various ionic species onto a number of different substances (Dzombak and Morel 1990). In our modelling we have assumed two different populations of surface reactive sites. SOH sites represent amphoteric aluminol and silanol groups on the mineral edge. Proton exchange at these sites is modelled with following reaction

$$
\begin{aligned}
& \equiv \mathrm{SOH}+\mathrm{H}^{+} \leftrightarrow \mathrm{\equiv SOH}_{2}{ }^{+} \\
& \equiv \mathrm{SOH} \leftrightarrow \mathrm{SSO}^{-}+\mathrm{H}^{+}
\end{aligned}
$$

Permanent charge, cation exchange sites $\left(\equiv X^{-}\right)$were also taken into account with reaction (3):

$\equiv \mathrm{XNa} \rightarrow \equiv \mathrm{X}^{-}+\mathrm{Na}^{+}$

Initial estimate for the surface sites densities of $\equiv \mathrm{X}^{-}$and $\equiv \mathrm{SOH}$ were obtained by optimizing the fit for the potentiometric titration curve. This modelling approach was adapted from previous successful applications for adsorption of metals and organics on kaolinite, montmorillonite (Ikhsan et al., 2005; Barbier et al., 2000; Bradbury and Bayens, 1999) and Laponite (Giannakopoulos et al., 2006). Including more than one type variable charge surface sites e.g. as in the case of montmorillonite did not improve the fit. On the other hand, the inclusion of permanent charge cation exchange sites has effect of the adsorption data at acidic $\mathrm{pH}$. The equilibrium constants $\left(\mathrm{K}_{\mathrm{int}}{ }^{+}\right.$or $\mathrm{K}_{\text {int }}{ }^{-}$refers to the reaction constant without the electrostatic correction) for the surface reactions are given by equations:

$$
\begin{gathered}
K_{\text {int }}^{+}=\frac{\left[\equiv S O H_{2}^{+}\right]}{[\equiv S O H]\left(H^{+}\right)} e^{\left[\frac{F \Psi_{0}}{R T}\right]} \\
K_{\text {int }}^{-}=\frac{\left[\equiv S O^{-}\right]\left(H^{+}\right)}{[\equiv S O H]} e^{\left[\frac{-F \Psi_{0}}{R T}\right]}
\end{gathered}
$$

where: $\Psi_{0}$ is the electrostatic double layer potential; $F$ is the Faraday constant; $R$ is the gas constant; and $T$ is the absolute temperature. The equilibrium constant of metal reacting with surface sites are expressed in the form 


$$
K_{\left(M^{+2}\right)}=\frac{\left[\equiv S O M^{+}\right]\left(H^{+}\right)}{[\equiv S O H]\left(M^{+2}\right)} e^{\left[\frac{F \Psi_{0}}{R T}\right]}
$$

The theoretical calculation were performed using the software FITEQL (Herbelin and Westall, 1999) assuming a Diffuse Layer Model (Dzombak and Morel, 1990).

\section{RESULTS AND DISCUSSION}

\subsection{Surface Charge of H.C. Zenith Montmorillonite}

The mass titration experiments for a HCM sample are shown in Figure $1 \mathrm{~A}$ for two values of ionic strength. In non buffered solution, the $\mathrm{pH}$ gradually changes with the addition of solid, asymptotically approaching a limiting value. Therefore the $\mathrm{pH}$ where the solid addition does not produce a $\mathrm{pH}$ shift, can be estimated by extrapolation.
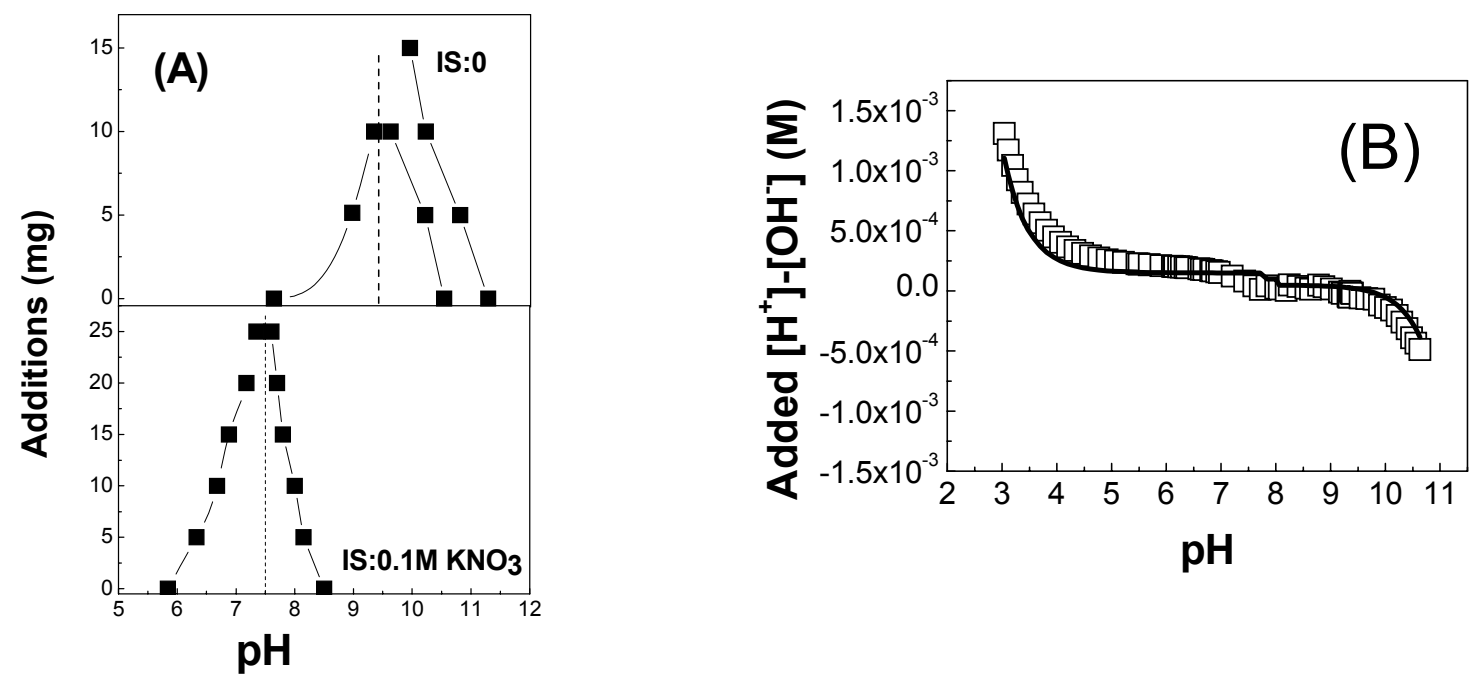

Figure 1. (A) Mass titration. (B) Potentiometric acid-base titration for the H.C.

The titration curve of a blank solution has been subtracted from the experimental data. Montmorillonite (open squares) experimental data (solid line) theoretical calculation using the protonation reactions described in Table 3

This value can be taken as a good approximation of the PZNC. For the HC-Zenith montmorillonite the data give PZNC 9.35 for IS=0 and PZNC 7.5 for IS $=0.1 \mathrm{KNO}_{3}$. Figure $1 \mathrm{~B}$ shows potentiometric titration for a HCM sample at I.S. $=0$. The lines represent the best fit of experimental data using the following values for protonation constants $\log \mathrm{K}_{\text {int }}^{+}=8.8$ and $\log \mathrm{K}_{\text {int }}^{-}=-9.8$. To verify the consistency between these values and the mass titration data we see that

$\mathrm{pH}_{\mathrm{PZNC}}=\frac{1}{2}\left(\left|\mathrm{pK}_{\text {Intr }}^{+}\right|+\left|\mathrm{pK}_{\mathrm{intr}}^{-}\right|\right)=9.3$

which consistent with the value 9.35 from mass titration at $\mathrm{I} . \mathrm{S}=0$. It is well known that montmorillonite particles carry two kinds of electrical charges a variable ( $\mathrm{pH}$ dependent) charge resulting from proton adsorption/desorption reaction of surface sites $\mathrm{SOH}$ and a structural negative charge from $\mathrm{X}^{-}$sites resulting in from isomorphous substitusion within the clay structure. The $\mathrm{X}^{-}$site concentration is intimately related with CEC of montmorillonite $(200 \mathrm{meq} / 100 \mathrm{~g})$ and its result in values of permanent charge density $\sigma_{0}=F\left[X^{-}\right] / \mathrm{s}=-47.9 \times 10^{-3} \mathrm{C}^{2} \mathrm{~m}^{2}$, for $\mathrm{s}=300 \mathrm{~m}^{2} \mathrm{gr}^{-1}$. Including $\sigma_{0}$ value in the calculation of the PZNC, the formula of Kraepiel and Morel (1996).

$$
\begin{aligned}
& \mathrm{pH}_{\mathrm{PZNC}}=\frac{1}{2}\left(\left|\mathrm{pK}_{\text {Intr }}^{+}\right|+\left|\mathrm{pK}_{\mathrm{intr}}^{-}\right|\right)-\frac{1}{2.3}\left(\frac{\mathrm{F} \Psi_{\mathrm{PZNC}}}{\mathrm{RT}}\right) \\
& \text { where: } \frac{\mathrm{F} \Psi_{\mathrm{PZNC}}}{\mathrm{RT}}=2 \operatorname{arcSinh}\left(\frac{\sigma_{0}}{0.1174 \mathrm{I}^{\frac{1}{2}}}\right)
\end{aligned}
$$


gives a point of zero charge 9.19. Thus, the permanent charge has a nonzero effect on the PZNC of montmorillonite. All the surface charge properties of HCM zenith clay are summarized in Table 2.

Table 2. Physicochemical Parameters of High C.E.C Zenith Clay Used in this Study

\begin{tabular}{cc}
\hline CEC & $186 \mathrm{meq}^{\mathrm{a}} 100 \mathrm{~g}$ \\
\hline $\mathrm{PZNC}$ & $9.5^{a}, 9.19^{*}$ \\
\hline $\mathrm{K}^{+}$int & $8.8^{\mathrm{a}}$ \\
\hline $\mathrm{K}_{\text {int }}$ & $9.8^{\mathrm{a}}$ \\
\hline $\mathrm{X}^{-}$ & $3 \mathrm{mM} \mathrm{g}^{-1}$ \\
\hline SOH concentration & $1.8 \mathrm{mM} \mathrm{g}^{-1}$ \\
\hline Partice size & $200 \mathrm{~nm}^{b}$ \\
\hline${ }^{\mathrm{a}}$ via SCM and equation 1, ${ }^{*}$ This work via eq. 8a,b \\
${ }^{\mathrm{b}}$ Stathi et al. (2009)
\end{tabular}

\subsection{Adsorption of metals}

Adsorption of $\mathrm{Pb}, \mathrm{Cd}, \mathrm{Cu}$ and $\mathrm{Zn}$ versus $\mathrm{pH}$ are presented in Figures 2-5. The metal-uptake per $\mathrm{Kg}$ of $\mathrm{HCM}$ is listed in Table 3.

Table 3. Amounts ( $\mathrm{mmol} \mathrm{kg}^{-1}$ ) of Adsorbed Heavy Metals at $\mathrm{pH}=7.00$

\begin{tabular}{cc}
\hline $\mathrm{Pb}$ & 4.05 \\
\hline $\mathrm{Cd}$ & 2.88 \\
\hline $\mathrm{Cu}$ & 3.48 \\
\hline $\mathrm{Zn}$ & 2.55
\end{tabular}

The data in Table 3 show that the HCM is characterized by a very high Pb-uptaking capacity. For the other metals high metal binding capacities are documented in Table 3, which exceed the capacities of other montmorillonites (Ikhsan et al., 2005; Barbier et al., 2000; Bradbury and Bayens, 1999; Bayens and Bradbury, 1997) including the reference Zenith clay (Balomenou et al., 2008).

\subsection{Theoretical Speciation}

The symbols in the figures represent experimental data and lines with open symbols are calculated using the parameters given in Table 4. The metal sorption edges were characterized by an initial sorption state where the uptake is stable. Taking into account the pKa values for the variable charge sites, Table 4, it is apparent that at acidic $\mathrm{pH}$ the prevailing positively surface charge sites $\equiv \mathrm{SOH}_{2}{ }^{+}$ are not favorable for metal adsorption. On the other hand, assuming that the adsorption at low $\mathrm{pH}$ involves only the adsorption at $\equiv \mathrm{X}^{-}$sites a consistent picture emerges, as shown from speciation schemes.
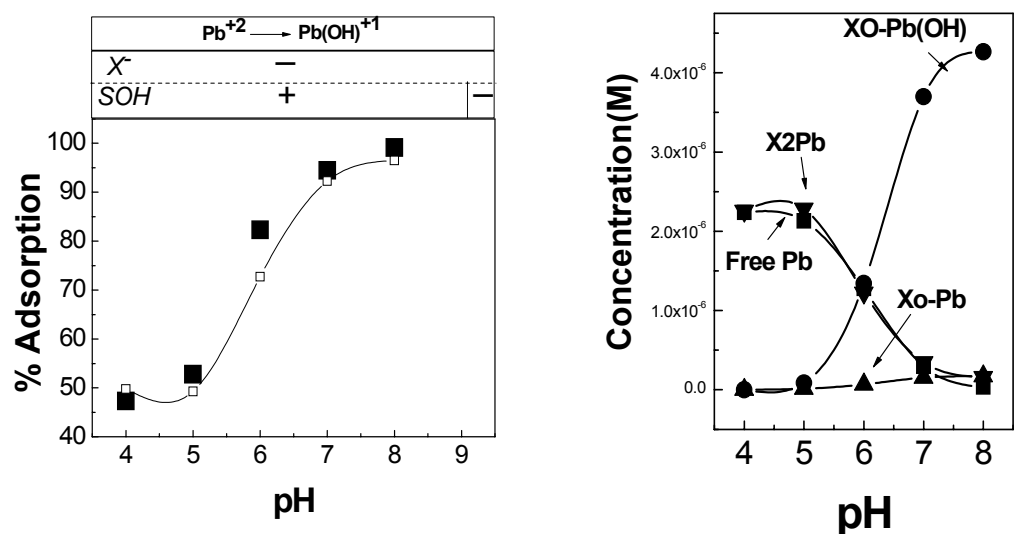

Figure 2. (Left) Adsorption of $\mathrm{Pb}$ on H.C. Zenith montmorillonite. Open symbols are theoretical calculations by using the parameters from Table 4 in FITEQL. At the top of the figures the Schindlerplot help the visualization of the charges of the interacting species as a function of the $\mathrm{pH}$.

(Right) Speciation analysis of the system clay- metal according to the calculations 

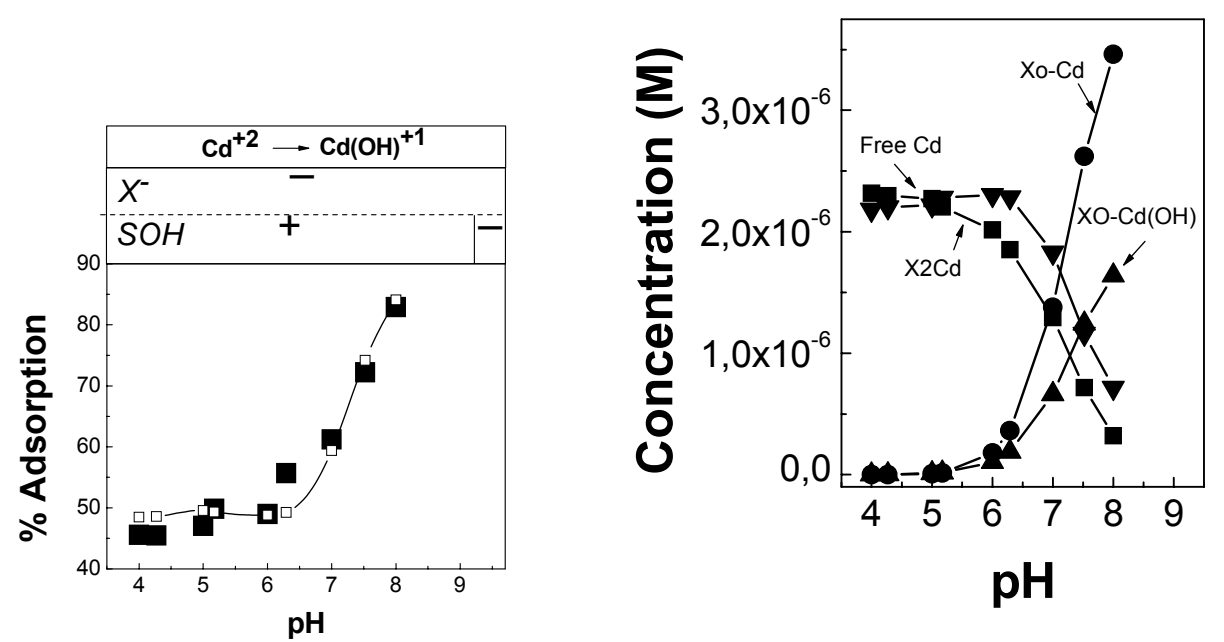

Figure 3. (Left) Adsorption of Cd on H.C. Zenith Zenith montmorillonite. Open symbols are theoretical calculations by using the parameters from Table 4 in FITEQL. (Right) Speciation analysis of the system clay- metal according to the calculations
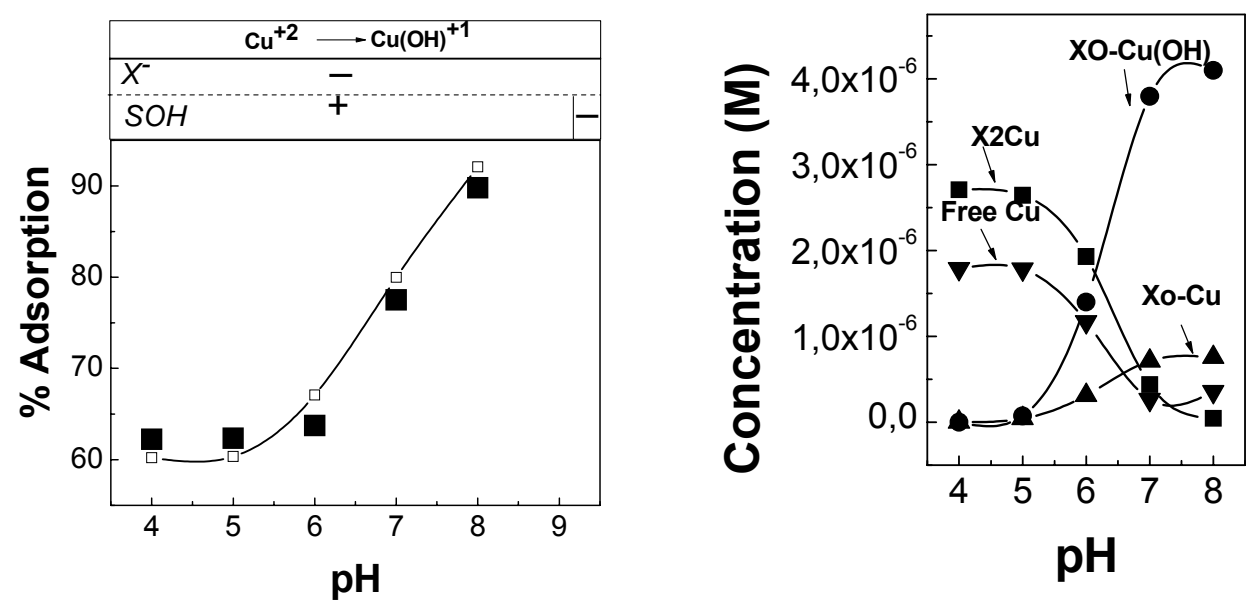

Figure 4. (Left) Adsorption of $\mathrm{Cu}$ on H.C. Zenith Zenith montmorillonite. Open symbols are theoretical calculations by using the parameters from Table 4 in FITEQL. (Right) Speciation analysis of the system clay- metal according to the calculations
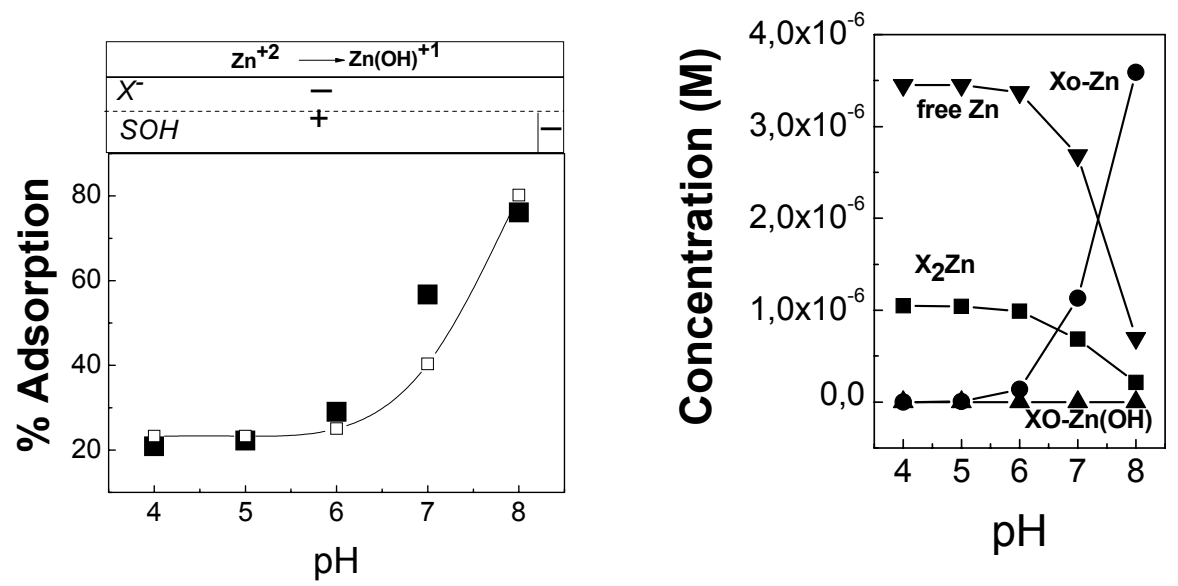

Figure 5. (Left) Adsorption of Zn on H.C. Zenith Zenith montmorillonite. Open symbols are theoretical calculations by using the parameters from Table 4 in FITEQL. (Right)Speciation analysis of the system clay- metal according to the calculations 
The present data show that the cation exchange sites can play a significant role in the adsorption of metals in smectite clays. This can be significant in cases where the CEC sites of a clay have significant concentration. In low-CEC clays i.e. such as kaoline CEC $20 \mathrm{meq} / 100 \mathrm{~g}$ (Sposito, 1989) the contribution of the permanent-charge sites is practically zero. Barbier et al. (Barbier et al., 2000) reported that the adsorption of $\mathrm{Pb}$ ions on Na-montmorillonite, CEC $\sim 80 \mathrm{meq} / 100 \mathrm{~g}$, is primarily via cation exchange, while surface hydroxyl groups seem to play a secondary role. Our present data reveal clearly that permanent-charge sites can become dominant in metal-uptake by clays. In addition it was shown that the permanent charge can influence the ionic-strength sensitivity of the PZC of the clay.

Table 4. Solution and Surface reactions for High CEC Zenith Montmorillonite

\begin{tabular}{|c|c|c|}
\hline & $\log K$ & Reference \\
\hline \multicolumn{3}{|l|}{ Dissociation of Water } \\
\hline $\mathrm{H}_{2} \mathrm{O} \leftrightarrow \mathrm{H}^{+}+\mathrm{OH}^{-}$ & 14 & \\
\hline \multicolumn{3}{|l|}{ Hydrolysis of Metals } \\
\hline $\mathrm{Pb}^{+2} \leftrightarrow \mathrm{Pb}(\mathrm{OH})^{+}+\mathrm{H}^{+}$ & 7.70 & Baes and Mesmer (1986) \\
\hline $\mathrm{Cd}^{+2} \leftrightarrow \mathrm{Cd}(\mathrm{OH})^{+}+\mathrm{H}^{+}$ & 10.0 & Baes and Mesmer (1986) \\
\hline $\mathrm{Cu}^{+2} \leftrightarrow \mathrm{Cu}(\mathrm{OH})^{+}+\mathrm{H}^{+}$ & 5.60 & Baes and Mesmer (1986) \\
\hline $\mathrm{Zn}^{+2} \leftrightarrow \mathrm{Zn}(\mathrm{OH})^{+}+\mathrm{H}^{+}$ & 9.80 & Baes and Mesmer (1986) \\
\hline \multicolumn{3}{|l|}{ Protonation of Zenith Clay } \\
\hline $\mathrm{SOH} \leftrightarrow \mathrm{SO}^{-}+\mathrm{H}^{+}$ & -9.80 & Stathi et al. (2009) \\
\hline $\mathrm{SOH}+\mathrm{H}^{+} \leftrightarrow \mathrm{SOH}_{2}^{+}$ & 8.80 & Stathi et al. (2009) \\
\hline \multicolumn{3}{|l|}{ Sorption of metals onto zenith clay } \\
\hline $\mathrm{X}+\mathrm{Pb}^{+2} \leftrightarrow\left[\mathrm{X}_{2} \mathrm{~Pb}\right]$ & 4.31 & This work \\
\hline $\mathrm{X}+\mathrm{Cd}^{+2} \leftrightarrow\left[\mathrm{X}_{2} \mathrm{Cd}\right]$ & 4.28 & This work \\
\hline $\mathrm{X}+\mathrm{Cu}^{+2} \leftrightarrow\left[\mathrm{X}_{2} \mathrm{Cu}\right]$ & 4.51 & This work \\
\hline $\mathrm{X}+\mathrm{Zn}^{+2} \leftrightarrow\left[\mathrm{X}_{2} \mathrm{Zn}\right]$ & 3.80 & This work \\
\hline $\mathrm{SOH}+\mathrm{Pb}^{+2} \leftrightarrow[\mathrm{SOPb}]^{+}+\mathrm{H}^{+}$ & 5.50 & This work \\
\hline $\mathrm{SOH}+\mathrm{Cd}^{+2} \leftrightarrow[\mathrm{SOCd}]^{+}+\mathrm{H}^{+}$ & 4.80 & This work \\
\hline $\mathrm{SOH}+\mathrm{Cu}^{+2} \leftrightarrow[\mathrm{SOCu}]^{+}+\mathrm{H}^{+}$ & 5.95 & This work \\
\hline $\mathrm{SOH}+\mathrm{Zn}^{+2} \leftrightarrow[\mathrm{SOZn}]^{+}+\mathrm{H}^{+}$ & 4.52 & This work \\
\hline $\mathrm{SOH}+\mathrm{Pb}(\mathrm{OH})^{+1} \leftrightarrow[\mathrm{SOPb}(\mathrm{OH})]+\mathrm{H}^{+}$ & 1.50 & This work \\
\hline $\mathrm{SOH}+\mathrm{Cd}(\mathrm{OH})^{+1} \leftrightarrow[\mathrm{SOCd}(\mathrm{OH})]+\mathrm{H}^{+}$ & 2.60 & This work \\
\hline $\mathrm{SOH}+\mathrm{Cu}(\mathrm{OH})^{+1} \leftrightarrow[\mathrm{SOCu}(\mathrm{OH})]+\mathrm{H}^{+}$ & 1.90 & This work \\
\hline $\mathrm{SOH}+\mathrm{Zn}(\mathrm{OH})^{+1} \leftrightarrow[\mathrm{SOZn}(\mathrm{OH})]+\mathrm{H}^{+}$ & 0.60 & This work \\
\hline
\end{tabular}

\section{REFERENCES}

Avena M.J. and De Pauli C. (1998) Proton adsorption and electrokinetics of an Argentinean montmorillonite, J. Colloid Interface Sci., 202, 195-204.

Baes C.F. and Mesmer R.E. (1986) The Hydrolysis of Cations, R.E. Kriegen Publishing Co., Malandar.

Balomenou G., Stathi P., Enotiadis A., Gournis D. and Deligiannakis Y. (2008) Physicochemical study of amino-functionalized organosilicon cubes intercalated in montmorillonite clay: $\mathrm{H}$-binding and metal uptake, J. Colloid Interface Science, 325, 74-83.

Barbier F., Duc G. and Petit-Raurel M. (2000) Adsorption of lead and cadmium ions from aqueous solution to the montmorillonite/water interface, Colloids Surf. A, 166, 153-159.

Bayens B. and Bradbury M.H. (1997) A mechanistic description of $\mathrm{Ni}$ and $\mathrm{Zn}$ sorption on Namontmorillonite .1. Titration and sorption measurements, J. Contaminant Hydrology, 27, 199-122. 
Bradbury M.H. and Bayens B. (1999) Modelling the sorption of $\mathrm{Zn}$ and $\mathrm{Ni}$ on Ca-montmorillonite, Geochimica et cosmochimica acta, 63, 325-336.

Bourikas K., Vakros J., Kordulis C. and Lycourgiotis A. (2003) Potentiometric mass titrations: Experimental and theoretical establishment of a new technique for determining the point of zero charge (PZC) of metal (hydr)oxides, J. Phys. Chem. B.,107, 9441-9451.

Dzombak D.A. and Morel F.M.M. (1990) Surface complezation Modeling, John Willey \& sons, New York.

Giannakopoulos E., Stathi P., Dimou K., Gournis D., Sanakis Y. and Deligiannakis Y. (2006) Adsorption and Radical Stabilisation of Humic Acid-Analogues and $\mathrm{Pb}^{2+}$ on Laponite Clay, Langmuir, 22, 68636873.

Herbelin A. and Westall J. (1999) FITEQL: A computer program for determination of chemical equilibrium constant from experimental data, Version 4.0; Report 99-01; Department of Chemistry, Oregon State University: Corvallis, OR.

Ikhsan J., Wells J.D., Johnson B.B. and Angove M.J. (2005) Surface complexation modeling of the sorption of Zn(II) by montmorillonite, Colloids Surf. A, 252, 33-41.

King R.D., Nocera D.G., Pinnavaia T.J. (1987) On the nature of electroactive sites in clay-modified electrodes, J. Electroanal. Chem., 236, 43-53.

Kraepiel A.M.L., Kellers K. and Morel F.M.M. (1999) A model for metal adsorption on montmorillonite, J. Colloid Interface Sci., 210, 43-54.

Kraepiel A.M.L. and Morel F.M.M. (1998) On the acid-base chemistry of permanently charge minerals, Envir. Sci. Techn., 32, 2829-2838

Schulthess C.P. and Sparks D.L. (1986) Back-titration technique for proton isotherm modeling of oxide surfaces, Soil. Sci.Soc. Am. J., 50, 1406-1411.

Sposito G. (1989) The Chemistry of soils, Oxford University Press, New York-Oxford.

Sposito G. (2004) The Surface Chemistry of Natural Particles, Oxford University Press, New York-Oxford.

Stathi P., Christoforidis K.C., Tsipis A., Chela C.D. and Deligiannakis Y. (2006) Effects of Dissolved Carboxylates and Carbonates on the Adsorption Properties of Thiram Disulfide Pesticides, Envir. Sci. Techn., 40, 221-226.

Stathi P., Papadas I., Enotiadis A., Gounis D. and Deligiannakis Y. (2009) Effects of Acetate on Cation Exchange Capacity of a Zn-Containing Montmorillonite: Physicochemical Significance and Metal Uptake, Langmuir, 25, 6825-6833. 